\title{
Chelatococcus sambhunathii sp. nov., a moderately thermophilic alphaproteobacterium isolated from hot spring sediment
}

Correspondence

Subrata K. Das

subratkdas@hotmail.com or

subrata@ils.res.in

\author{
Digvijay Panday and Subrata K. Das
}

Institute of Life Sciences, Department of Biotechnology, Nalco Square, Bhubaneswar 751023 , India

\begin{abstract}
A moderately thermophilic bacterial strain $\left(\mathrm{HT} 4^{\top}\right)$ isolated from a hot spring sediment was characterized phenotypically and phylogenetically. Cells were Gram-negative, aerobic, non-sporulating, rod-shaped and motile by means of a single polar flagellum. Both oxidase and catalase activities were positive. Heterotrophic growth was observed at $\mathrm{pH} 6.0-8.5$ and at 20-50 ${ }^{\circ} \mathrm{C}$; optimum growth occurred at $\mathrm{pH} 7.5-8.0$ and $37-42{ }^{\circ} \mathrm{C}$. The major cellular fatty acids were $\mathrm{C}_{14: 0} 3-\mathrm{OH}, \mathrm{C}_{18: 0} 3-\mathrm{OH}, \mathrm{C}_{18: 1} 2-\mathrm{OH}, \mathrm{C}_{18: 1} \omega 7 \mathrm{c}$ and $\mathrm{C}_{19: 0}$ cyclo $\omega 8 \mathrm{c}$. The DNA $\mathrm{G}+\mathrm{C}$ content of strain $\mathrm{HT}^{\top}{ }^{\top}$ was 67.8 mol\%. 16S rRNA gene sequence analysis indicated that strain $\mathrm{HT} 4^{\top}$ clustered within the radiation of the genus Chelatococcus and showed $99.0 \%$ similarity with Chelatococcus daeguensis CCUG $54519^{\top}$ and $96 \%$ similarity with Chelatococcus asaccharovorans DSM $6462^{\top}$. However, levels of DNA-DNA relatedness between strain $\mathrm{HT}^{\top}$ and Chelatococcus daeguensis CCUG $54519^{\top}$ and Chelatococcus asaccharovorans DSM $6462^{\top}$ were 52 and $20 \%$, respectively. On the basis of the phenotypic, physiological and chemotaxonomic data, 16S rRNA gene sequence analysis and DNA-DNA hybridization results, strain $\mathrm{HT}^{\top}{ }^{\top}$ is considered to represent a novel species of the genus Chelatococcus, for which the name Chelatococcus sambhunathii sp. nov. is proposed. The type strain is $\mathrm{HT} 4^{\top}$ (=DSM $\left.18167^{\top}=J C M 14988^{\top}\right)$.
\end{abstract}

Exploration of bacterial species in hot springs is of importance owing to the intriguing biogeochemistry and extreme conditions of these environments. The vast majority of bacterial species belonging to the most recent lines of descent, such as the Proteobacteria, are mesophilic, although slightly thermophilic, moderately thermophilic and even extremely thermophilic species have been described from these bacterial lineages. The Alphaproteobacteria includes many mesophilic species, but also a few slightly thermophilic or moderately thermophilic species, namely Rubritepida flocculans (Alarico et al., 2002), Porphyrobacter cryptus (Rainey et al., 2003), Phenylobacterium lituiforme (Kanso \& Patel, 2004), Acidicaldus organivorus (Johnson et al., 2006), Nesiotobacter exalbescens (Donachie et al., 2006) and Rubellimicrobium thermophilum (Denner et al., 2006). Several hot springs exist on the Indian subcontinent (Gupta et al., 1975), but the micro-organisms present in these environments have been little studied (but

The GenBank/EMBL/DDBJ accession number for the 16S rRNA gene sequence of strain $\mathrm{HT}^{\top}{ }^{\top}$ is DO322070.

A supplementary table detailing the fatty acid composition of strain $\mathrm{HT}^{\top}$ and other members of the genus Chelatococcus is available with the online version of this paper. see Ghosh et al., 2003). This paper describes a bacterial strain $\left(\mathrm{HT}^{\mathrm{T}}\right)$ isolated from a hot spring located at Athamallik, Orissa, India. Based on the results of the present polyphasic taxonomic study, strain $\mathrm{HT}^{\mathrm{T}}$ is considered to represent a novel species of the genus Chelatococcus.

The hot spring at Athamallik is situated at $80 \mathrm{~m}$ above sea level. It has a series of outlets within a radius of $70 \mathrm{~m}$. The water temperature at the main outlet was $56{ }^{\circ} \mathrm{C}$ and in the surrounding areas ranged from 43 to $50{ }^{\circ} \mathrm{C}$. The $\mathrm{pH}$ of sediment samples taken for analysis was 7.4. Sediment samples were transported to the laboratory without temperature control and subsequently transferred into $250-\mathrm{ml}$ conical flasks containing $50 \mathrm{ml}$ nutrient broth (Difco) and incubated on a shaker (ISF-1-V; Adolf Kuhner AG) at 200 r.p.m. and $45{ }^{\circ} \mathrm{C}$. After 2 days incubation, the contents of the flasks were serially diluted and plated onto nutrient agar medium (Difco) and incubated at $37^{\circ} \mathrm{C}$ for 4 days. Several colonies that developed at $37^{\circ} \mathrm{C}$ were picked and purified by repeated streaking on the same medium. A colony with a mucoid cream colour was selected for further analysis; this was designated strain $\mathrm{HT}^{\mathrm{T}}$.

Colonies of strain $\mathrm{HT}^{\mathrm{T}}$ grown on nutrient agar were circular, $1.5-2.5 \mathrm{~mm}$ in diameter, mucoid and smooth. 
Single colonies appeared within $2-3$ days at $37^{\circ} \mathrm{C}$. Cell morphology was examined by using transmission electron microscopy (model FEI MORGAGNI 268D). The presence of flagella was determined by using cells that were placed onto a carbon-coated grid and negatively stained with $2.0 \%$ phosphotungstic acid (Sharma et al., 1989). Cells were rod-shaped, $0.8-1.0 \mu \mathrm{m}$ wide and $2.3-2.7 \mu \mathrm{m}$ long, motile by means of a single polar flagellum and generally occurred singly (Fig. 1). Cells stained Gram-negative and did not form spores. Oxidase activity was assayed with discs impregnated with dimethyl $p$-phenylenediamine (Himedia). Catalase activity was assayed by mixing a pellet of a freshly centrifuged culture with a drop of hydrogen peroxide $(10 \%, \mathrm{v} / \mathrm{v})$. Anaerobic growth was determined on tripticase soy agar (TSA; MP Biomedical LLC) and on TSA supplemented with potassium nitrate $(0.1 \%, \mathrm{w} / \mathrm{v})$ in an anaerobic jar (BD GasPak EZ system; Becton Dickinson), prepared according to the manufacturer's instructions. The jar was incubated at $37{ }^{\circ} \mathrm{C}$ and examined after 7 days. All other routine biochemical tests and procedures were performed as described by Panda et al. (2009). Phenotypic properties of strain $\mathrm{HT}_{4}^{\mathrm{T}}$ are given in the species description and characteristics that differentiate strain $\mathrm{HT}_{4}{ }^{\mathrm{T}}$ from Chelatococcus daeguensis CCUG $54519^{\mathrm{T}}$ and Chelatococcus asaccharovorans DSM $6462^{\mathrm{T}}$ are given in Table 1.

Growth occurred at $20-50{ }^{\circ} \mathrm{C}$, with optimum growth at $37-42{ }^{\circ} \mathrm{C}$. Heterotrophic growth was observed at $\mathrm{pH} 6.0$ 8.5, with optimum growth at $\mathrm{pH} 7.5-8.0$. Utilization of organic compounds other than amino acids was examined

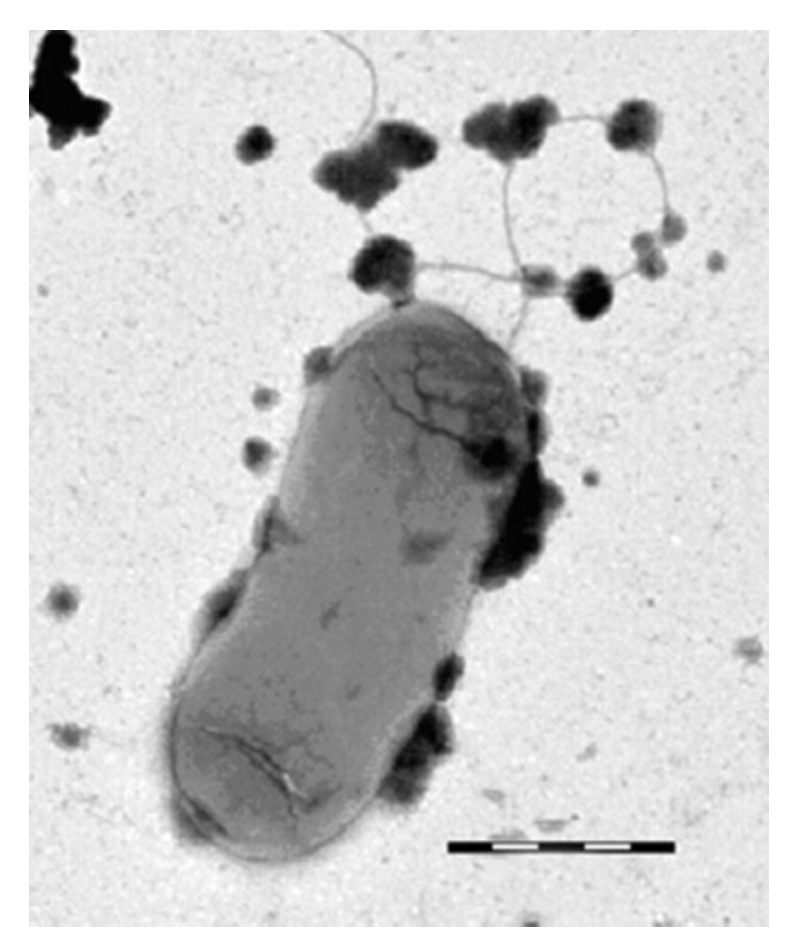

Fig. 1. Electron micrograph of a cell of strain $\mathrm{HT} 4^{\top}$, showing a single polar flagellum. Bar, $1 \mu \mathrm{m}$. in mineral salts medium containing potential organic carbon sources at a concentration of $0.5 \%(\mathrm{w} / \mathrm{v})$. Utilization of amino acids as sole carbon sources was tested by using single amino acids at a concentration of $0.2 \%(\mathrm{w} / \mathrm{v})$. The mineral salts medium contained (per litre distilled water): $4.0 \mathrm{~g} \mathrm{Na}_{2} \mathrm{HPO}_{4}, 1.5 \mathrm{~g} \mathrm{KH}_{2} \mathrm{PO}_{4}, 0.01 \mathrm{~g}$ $\mathrm{CaCl}_{2} .5 \mathrm{H}_{2} \mathrm{O}, 1.0 \mathrm{~g} \mathrm{NH}_{4} \mathrm{Cl}$ and $0.5 \mathrm{~g} \mathrm{MgSO}_{4} \cdot 7 \mathrm{H}_{2} \mathrm{O}$. The medium was adjusted to $\mathrm{pH} 7.5$ with $10 \mathrm{M} \mathrm{NaOH}$. Utilization of nitrilotriacetate was tested by using the synthetic medium defined by Egli et al. (1988).

As strain $\mathrm{HT}^{\mathrm{T}}$ was isolated from a hot spring, aerobic growth on reduced sulfur compounds was tested in mineral salts medium supplemented with different inorganic sulfur sources (thiosulfate, tetrathionate or elemental sulfur) at a concentration of $0.1-1.0 \mathrm{~g}^{-1}$ in addition to yeast extract powder $\left(2.0 \mathrm{~g} \mathrm{l}^{-1}\right)$. The concentration of sulfur compounds in the culture filtrates was determined as described by Kelly et al. (1969). Sulfate content was determined according to Berglund \& Sorbo (1960) and Gleen \& Quastel (1952). Strain HT4 ${ }^{\mathrm{T}}$ was unable to utilize these sulfur sources; it therefore appears to be a chemoorganotroph. Yeast extract-mineral salts medium containing $0-5.0 \%(\mathrm{w} / \mathrm{v}) \mathrm{NaCl}$ was inoculated and incubated at $37^{\circ} \mathrm{C}$ for 4 days to test for salt tolerance. On this medium strain $\mathrm{HT}_{4}^{\mathrm{T}}$ was able to grow in the presence of $0-3.0 \%$ $(\mathrm{w} / \mathrm{v}) \mathrm{NaCl}$ but not in the presence of $4 \% \mathrm{NaCl}$.

Antibiotic resistance of strain $\mathrm{HT}^{\mathrm{T}}{ }^{\mathrm{T}}$ was checked on nutrient agar containing different concentrations of antibiotics. Strain $\mathrm{HT}^{\mathrm{T}}$ was resistant to kanamycin $\left(50 \mu \mathrm{g} \mathrm{ml}^{-1}\right)$ and neomycin $\left(30 \mu \mathrm{g} \mathrm{ml}^{-1}\right)$, but was susceptible to streptomycin $\left(25 \mu \mathrm{g} \mathrm{ml}^{-1}\right)$, chloramphenicol $\left(30 \mu \mathrm{g} \mathrm{ml}^{-1}\right)$, tetracycline $\left(15 \mu \mathrm{g} \mathrm{ml}^{-1}\right)$, nalidixic acid $\left(20 \mu \mathrm{g} \mathrm{ml}^{-1}\right)$, rifampicin $\left(20 \mu \mathrm{g} \mathrm{ml}^{-1}\right)$ and ampicillin $\left(40 \mu \mathrm{g} \mathrm{ml}^{-1}\right)$.

For estimation of the $\mathrm{G}+\mathrm{C}$ content of the genomic DNA of strain $\mathrm{HT}^{\mathrm{T}}$, DNA was enzymically degraded into nucleotides as described by Mesbah et al. (1989). The nucleoside mixture obtained was then separated by HPLC (Shimadzu Corp.) by using a VYDAC201 SP54 analytical column $(\mathrm{C} 18,5 \mu \mathrm{m}, 250 \times 4.6 \mathrm{~mm})$ equipped with a guard column (201 GD54H; Vydac). Operating conditions were as described by Tamaoka \& Komagata (1984): temperature $45^{\circ} \mathrm{C} ; 10 \mu \mathrm{l}$ sample; solvent $0.3 \mathrm{M}\left(\mathrm{NH}_{4}\right) \mathrm{H}_{2} \mathrm{PO}_{4}$ /acetonitrile, $40: 1(\mathrm{v} / \mathrm{v}) ; \mathrm{pH} 4.4 ; 1.3 \mathrm{ml} \mathrm{min}^{-1}$. Non-methylated lamda phage DNA (Sigma) was used as the calibration reference. The $\mathrm{G}+\mathrm{C}$ content of the genomic DNA of strain $\mathrm{HT}^{\mathrm{T}}$ was $67.8 \mathrm{~mol} \%$, a value consistent with membership of the genus Chelatococcus (Egli \& Auling, 2005).

Cellular fatty acids were analysed from cells grown on TSA plates for 3 days at $30{ }^{\circ} \mathrm{C}$. Cells were saponified and transmethylated as described by Kuykendall et al. (1988). The fatty acid methyl ester mixtures were separated by using the Sherlock Microbial Identification System (MIS) (MIDI, Microbial ID), which consisted of an Agilent model 6890N gas chromatograph. The fatty acid profile of strain $\mathrm{HT}_{4}^{\mathrm{T}}$ comprised $\mathrm{C}_{16: 0}\left(1.2 \%\right.$ of the total), $\mathrm{C}_{17: 0}(1.5 \%), \mathrm{C}_{18: 0}$ (1.7\%), $\mathrm{C}_{14: 0} 3-\mathrm{OH}(3.0 \%), \mathrm{C}_{18: 0} 3-\mathrm{OH}(3.4 \%), \mathrm{C}_{18: 1}$ 
Table 1. Differential characteristics between strain $\mathrm{HT}^{\top}$ (C. sambhunathii sp. nov.) and the type strains of recognized Chelatococcus species

+, Positive; -, negative. All tests were performed concurrently with the same methods and under the same conditions.

\begin{tabular}{|c|c|c|c|}
\hline Characteristic & Strain $\mathrm{HT} 4^{\mathrm{T}}$ & $\begin{array}{l}\text { Chelatococcus daeguensis } \\
\text { CCUG } 54519^{T}\end{array}$ & $\begin{array}{c}\text { Chelatococcus asaccharovorans } \\
\text { DSM } 6462^{\mathrm{T}}\end{array}$ \\
\hline Isolation source & Hot spring & Textile waste matter & Wastewater, soil \\
\hline Motility & + & + & - \\
\hline Hydrolysis of gelatin & + & - & + \\
\hline $\mathrm{NaCl}$ tolerance range $(\mathrm{w} / \mathrm{v})$ & $0.0-3.0$ & $0.0-5.0$ & $0.0-2.5$ \\
\hline $\begin{array}{l}\text { Mannose, xylose, gluconate, } \\
\text { D-arabinose, cysteine }\end{array}$ & - & + & + \\
\hline $\begin{array}{l}\text { Glycerol, salicin, inositol, } \\
\text { adonitol, cellobiose, xylitol, } \\
\text { aesculin, rhamnose, galactose, } \\
\text { methionine, threonine, } \\
\text { tyrosine, lysine }\end{array}$ & - & + & - \\
\hline \multicolumn{4}{|l|}{ Acid production from: } \\
\hline $\begin{array}{l}\text { Glucose, inositol, arabinose, } \\
\text { rhamnose } \\
\text { pH for growth }\end{array}$ & - & + & - \\
\hline Range & $6.0-8.5$ & $5.5-10$ & $5.5-9.5$ \\
\hline Optimum & $7.5-8.0$ & $7.0-7.5$ & $7.0-8.0$ \\
\hline
\end{tabular}

2-OH (7.1 \%), $\mathrm{C}_{18: 1} \omega 7 c(73.1 \%), \mathrm{C}_{19: 0}$ cyclo $\omega 8 c(7.8 \%)$ and $\mathrm{C}_{20: 1} \omega 7 c(0.8 \%)$. Although strain $\mathrm{HT}^{\mathrm{T}}$ showed a fatty acid profile typical of the genus Chelatococcus (Yoon et al., 2008), it could be distinguished from the type strain of its closest phylogenetic neighbour (see Supplementary Table S1 in IJSEM online), Chelatococcus daeguensis CCUG 54519 ${ }^{\mathrm{T}}$, based on the absence of $\mathrm{C}_{16: 1} \omega 7 c$, iso- $\mathrm{C}_{15: 0} 2-\mathrm{OH}$ and $\mathrm{C}_{17: 0}$ cyclo.

Extraction of genomic DNA and PCR amplification of the $16 \mathrm{~S}$ rRNA gene were carried out as described by Das et al. (1996). The gel-purified 16S rRNA gene was sequenced by using a CEQ Dye terminator cycle sequencing kit in a model CEQ 8000 automated DNA sequencer (Panda et al., 2009). The $16 \mathrm{~S}$ rRNA gene sequence of strain $\mathrm{HT} 4^{\mathrm{T}}$ was aligned with representative reference sequences of members of the Alphaproteobacteria by using MEGA version 4.0 (Tamura et al., 2007). The method of Jukes and Cantor (1969) was used to calculate evolutionary distances. Tree topologies and statistical significance of branch points were tested based on 100 bootstrap resamplings of the neighbour-joining data (Felsenstein, 1985).

Comparative analysis of 1378-nt positions of the 16S rRNA gene sequence of strain $\mathrm{HT}_{4}^{\mathrm{T}}$ with those of other members of the Alphaproteobacteria showed that strain $\mathrm{HT} 4^{\mathrm{T}}$ was related closely to members of this lineage (Fig. 2). 16S rRNA gene sequence analysis indicated that strain $\mathrm{HT}_{4}^{\mathrm{T}}$ was related most closely to Chelatococcus daeguensis CCUG 54519 $(99 \%$ similarity) (Yoon et al., 2008), followed by Chelatococcus asaccharovorans DSM $6462^{\mathrm{T}}(96 \%)$, Beijerinckia mobilis
DSM $2326^{\mathrm{T}}$ and Corbulabacter subterraneus DSM $14364^{\mathrm{T}}$ (94\%), and Bosea thiooxidans DSM 9653 ${ }^{\mathrm{T}}$ (93\%).

DNA-DNA hybridization experiments were carried out between strain $\mathrm{HT}_{4}^{\mathrm{T}}$ and Chelatococcus daeguensis CCUG $54519^{\mathrm{T}}$ and Chelatococcus asaccharovorans DSM $6462^{\mathrm{T}}$ following the method of Ezaki et al. (1989) by using a ${ }^{32} \mathrm{P}-$ labelled probe. Experiments were performed in triplicate with either $\mathrm{HT}_{4}^{\mathrm{T}}$ or Chelatococcus daeguensis DNA as probe. Mean levels of DNA-DNA relatedness between strain $\mathrm{HT}^{\mathrm{T}}$ and Chelatococcus daeguensis CCUG $54519^{\mathrm{T}}$ and Chelatococcus asaccharovorans DSM $6462^{\mathrm{T}}$ were 52 and $20 \%$, respectively. Therefore, considering the $70 \%$ DNADNA relatedness cut-off point recommended for bacterial species delineation (Wayne et al., 1991; Stackebrandt \& Goebel, 1994), strain $\mathrm{HT}_{4}^{\mathrm{T}}$ should be regarded as representing a novel species of the genus Chelatococcus.

Based on phenotypic properties, cellular fatty acid analysis, phylogenetic analysis and DNA-DNA relatedness data, strain $\mathrm{HT}_{4}^{\mathrm{T}}$ is considered to represent a novel species of the genus Chelatococcus, for which the name Chelatococcus sambhunathii sp. nov. is proposed.

\section{Description of Chelatococcus sambhunathii sp. nov.}

Chelatococcus sambhunathii (sam.bhu.na.thi'i. N.L. masc. gen. n. sambhunathii of Sambhunath, named after Dr Sambhunath De, an eminent microbiologist in India). 


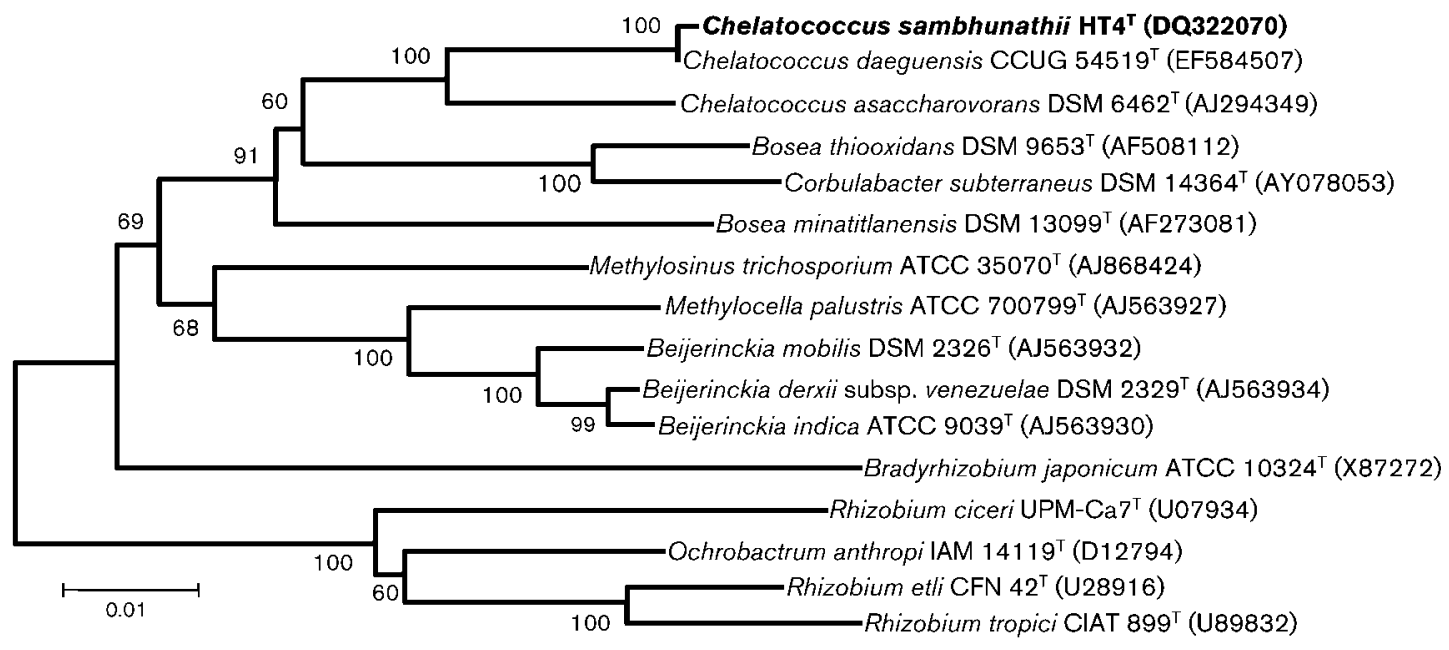

Fig. 2. Neighbour-joining phylogenetic tree showing the position of strain $\mathrm{HT}^{\top}{ }^{\top}$ among related taxa based on $16 \mathrm{~S}$ rRNA gene sequences. Bootstrap values as percentages of 100 resamplings are shown at branch points. Bar, 0.01 substitutions per nucleotide position.

Cells are rods that are $0.8-1.0 \mu \mathrm{m}$ wide and $2.3-2.7 \mu \mathrm{m}$ long. Cells usually occur singly, and are motile by means of a single polar flagellum. Gram-negative. Catalase- and oxidase-positive. Able to grow at $20-50{ }^{\circ} \mathrm{C}$ and $\mathrm{pH}$ 6.0-8.5. Colonies on nutrient agar medium are round, mucoid and smooth. Positive for arginine dihydrolase, gelatin liquefaction, growth on MacConkey agar, King's A and King's B media, and nitrate reductase. Negative for the methyl red and Voges-Proskauer tests, indole production, urease, starch hydrolysis and $\mathrm{H}_{2} \mathrm{~S}$ production. Anaerobic growth occurs in the presence of nitrate. Positive for assimilation of proline, asparagine, valine, glutamine, glutamic acid, histidine, alanine, aspartic acid, leucine, isoleucine, serine and citrate, but negative for assimilation of sucrose, mannitol, sorbitol, oxalate, raffinose, sorbose, maltose, lactose, phenylalanine, arginine and tryptophan. The fatty acid profile comprises $\mathrm{C}_{16: 0}, \mathrm{C}_{17: 0}, \mathrm{C}_{18: 0}, \mathrm{C}_{14: 0} 3-\mathrm{OH}$, $\mathrm{C}_{18: 0} 3-\mathrm{OH}, \mathrm{C}_{18: 1} 2-\mathrm{OH}, \mathrm{C}_{18: 1} \omega 7 c, \mathrm{C}_{19: 0}$ cyclo $\omega 8 c$ and $\mathrm{C}_{20: 1} \omega 7 c$. The DNA $\mathrm{G}+\mathrm{C}$ content of the type strain is $67.8 \mathrm{~mol} \%$.

The type strain, $\mathrm{HT}^{\mathrm{T}}\left(=\mathrm{DSM} 18167^{\mathrm{T}}=\mathrm{JCM} 14988^{\mathrm{T}}\right)$, was isolated from a hot spring in India.

\section{Acknowledgements}

We are grateful to Professor R. M. Kroppenstedt and Dr P. Schumann of the Deutsche Sammlung von Mikroorganismen und Zellkulturen GmbH (DSMZ, Braunschweig, Germany) for their help with fatty acid composition and DNA G $+\mathrm{C}$ content analyses. Chelatococcus asaccharovorans DSM $6462^{\mathrm{T}}$ and Chelatococcus daeguensis CCUG $54519^{\mathrm{T}}$ used in this study were provided by the DSMZ and Culture Collection, University of Göteborg, Sweden. This work was supported by the Department of Biotechnology, Ministry of Science and Technology, Government of India.

\section{References}

Alarico, S., Rainey, F. A., Empadinhas, N., Schumann, P., Nobre, M. F. \& da Costa, M. S. (2002). Rubritepida flocculans gen. nov., sp. nov., a new slightly thermophilic member of the alpha-1 subclass of the Proteobacteria. Syst Appl Microbiol 25, 198-206.

Berglund, F. \& Sorbo, B. H. (1960). Turbidimetric analysis of inorganic sulfate in serum, plasma and urine. Scand J Clin Lab Invest 12, 147-153.

Das, S. K., Mishra, A. K., Tindall, B. J., Rainey, F. A. \& Stackebrandt, E. (1996). Oxidation of thiosulfate by a new bacterium, Bosea thiooxidans (strain BI-42) gen. nov., sp. nov.: analysis of phylogeny based on chemotaxonomy and $16 \mathrm{~S}$ ribosomal DNA sequencing. Int $J$ Syst Bacteriol 46, 981-987.

Denner, E. M. B., Kolari, M., Hoornstra, D., Tsitko, I., Kämpfer, P., Busse, H.-J. \& Salkinoja-Salonen, M. (2006). Rubellimicrobium thermophilum gen. nov., sp. nov., a red-pigmented, moderately thermophilic bacterium isolated from coloured slime deposits in paper machines. Int J Syst Evol Microbiol 56, 1355-1362.

Donachie, S. P., Bowman, J. P. \& Alam, M. (2006). Nesiotobacter exalbescens gen. nov., sp. nov., a moderately thermophilic alphaproteobacterium from an Hawaiian hypersaline lake. Int J Syst Evol Microbiol 56, 563-567.

Egli, T. W. \& Auling, G. (2005). Genus Chelatococcus. In Bergey's Manual of Systematic Bacteriology, Part C, vol. 2, 2nd edn, pp. 433437. Edited by D. J. Brenner, N. R. Krieg \& J. T. Stanley. New York: Springer.

Egli, T. W., Weilenmann, H.-U., El-Banna, T. \& Auling, G. (1988). Gram-negative, aerobic, nitrilotriacetate-utilizing bacteria from wastewater and soil. Syst Appl Microbiol 10, 297-305.

Ezaki, T., Hashimoto, Y. \& Yabuuchi, E. (1989). Fluorometric deoxyribonucleic acid-deoxyribonucleic acid hybridization in microdilution wells as an alternative to membrane filter hybridization in which radioisotopes are used to determine genetic relatedness among bacterial strains. Int J Syst Bacteriol 39, 224-229.

Felsenstein, J. (1985). Confidence limits on phylogenies: an approach using the bootstrap. Evolution 39, 783-791. 
Ghosh, D., Bal, B., Kashyap, V. K. \& Pal, S. (2003). Molecular phylogenetic exploration of bacterial diversity in a Bakreshwar (India) hot spring and culture of Shewanella-related thermophiles. Appl Environ Microbiol 69, 4332-4336.

Gleen, H. \& Quastel, J. H. (1952). Sulfur metabolism in soil. Appl Microbiol 1, 70-77.

Gupta, M. L., Narain, H. \& Saxena, V. K. (1975). Geochemistry of thermal waters from various geothermal provinces of India. In Proceedings of the Grenoble Symposium of the International Association of Hydrological Sciences, pp. 47-58. Wallingford, UK: IAHS Press, Institute of Hydrology.

Johnson, D. B., Stallwood, B., Kimura, S. \& Hallberg, K. B. (2006). Isolation and characterization of Acidicaldus organivorus, gen. nov., sp. nov.: a novel sulfur-oxidizing, ferric iron-reducing thermo-acidophilic heterotrophic Proteobacterium. Arch Microbiol 185, 212-221.

Jukes, T. H. \& Cantor, C. R. (1969). Evolution of protein molecules. In Mammalian Protein Metabolism, vol. 3, pp. 21-132. Edited by H. N. Munro. New York: Academic Press.

Kanso, S. \& Patel, B. K. (2004). Phenylobacterium lituiforme sp. nov., a moderately thermophilic bacterium from a subsurface aquifer, and emended description of the genus Phenylobacterium. Int J Syst Evol Microbiol 54, 2141-2146.

Kelly, D. P., Chambers, L. A. \& Trudinger, P. A. (1969). Cyanolysis and spectrophotometric estimation of trithionate in mixture with thiosulfate and tetrathionate. Anal Chem 41, 898-901.

Kuykendall, L. D., Roy, M. D., O’Neill, J. J. \& Devine, T. E. (1988). Fatty acids, antibiotic resistance and deoxyribonucleic acid homology groups of Bradyrhizobium japonicum. Int J Syst Bacteriol 38, 358-361.

Mesbah, M., Premachandran, U. \& Whitman, W. B. (1989). Precise measurement of the $\mathrm{G}+\mathrm{C}$ content of deoxyribonucleic acid by highperformance liquid chromatography. Int J Syst Bacteriol 39, 159-167.
Panda, S. K., Jyoti, V., Bhadra, B., Nayak, K. C., Shivaji, S., Rainey, F. A. \& Das, S. K. (2009). Thiomonas bhubaneswarensis sp. nov., an obligately mixotrophic, moderately thermophilic, thiosulfate-oxidizing bacterium. Int J Syst Evol Microbiol 59, 2171-2175.

Rainey, F. A., Silva, J., Nobre, M. F., Silva, M. T. \& da Costa, M. S. (2003). Porphyrobacter cryptus sp. nov., a novel slightly thermophilic, aerobic, bacteriochlorophyll a-containing species. Int J Syst Evol Microbiol 53, 35-41.

Sharma, D. P., Thomas, C., Hall, R. H., Levine, M. M. \& Attridge, S. R. (1989). Significance of toxin coregulated pili as protective antigens of Vibrio cholerae in the infant mouse model. Vaccine 7 , 451-456.

Stackebrandt, E. \& Goebel, B. M. (1994). Taxonomic note: a place for DNA-DNA reassociation and $16 \mathrm{~S}$ rRNA sequence analysis in the present species definition in bacteriology. Int J Syst Bacteriol 44, 846849.

Tamaoka, J. \& Komagata, K. (1984). Determination of DNA base composition by reversed-phase high-performance liquid chromatography. FEMS Microbiol Lett 25, 125-128.

Tamura, K., Dudley, J., Nei, M. \& Kumar, S. (2007). MEGA4: molecular evolutionary genetics analysis (MEGA) software version 4.0. Mol Biol Evol 24, 1596-1599.

Wayne, L. G., Good, R. C., Krichevsky, M. I., Blacklock, Z., David, H. L., Dawson, D., Gross, W., Hawkins, J., Levy-Frebault, V. V. \& other authors (1991). Fourth report of the cooperative, open-ended study of slowly growing mycobacteria by the International Working Group on Mycobacterial Taxonomy. Int J Syst Bacteriol 41, 463-472.

Yoon, J. H., Kang, S. J., Im, W. T., Lee, S. T. \& Oh, T. K. (2008). Chelatococcus daeguensis sp. nov., isolated from wastewater of a textile dye works, and emended description of the genus Chelatococcus. Int $\mathrm{J}$ Syst Evol Microbiol 58, 2224-2228. 